\title{
Development Of Electrical Installation Learning Media With Delphi Language
}

\author{
Bagus Dwi Cahyono*, Dahliya Sulastri \\ Sultan Ageng Tirtayasa University, Indonesia \\ *Corresponding author E-mail: bagus.dwicahyono@untirta.ac.id
}

\begin{abstract}
Manuscript received 15 April 2021; revised 1 May 2021; accepted 15 June 2021. Date of publication 3 July 2021
Abstract

Learning Media is a learning tool that is used by someone by using tools that are made to facilitate the delivery of material when teaching at school. Things like that really help teachers in teaching in schools and are a solution to make students happy when learning and not feel bored. One of the learning materials in Vocational High Schools is electrical installation material. Introducing electrical installation material will be very difficult if only with books. Therefore this study aims to adopt material about electrical installations in a computer system. This system is called the Electrical Installation Learning Media in Delphi Language. This system is used to determine the number of light points on an electrical installation from the room size indicator and the amount of lux to be achieved. In addition, the system provides a brief description of the electrical installation material. In this system the electrical installation input data is entered into the computer manually. In building this system, Delphi 7 and Inno Set Up Compiler software are used as installers. The method used in this research is Research and Development (R\&D), with the following stages: (1) preliminary research; (2) designing software; (3) collection of materials; (4) initial product development; (5) validation of instructional media experts; (6) product analysis and revision; (8) testing the media in learning; and (9) the final product of the instructional media. The results show that: (1) the results of the feasibility test according to electrical installation experts are that this system is suitable to be used as a learning medium in electrical installation subjects in vocational schools because it contains an explanation of the calculation method of an electrical installation in detail; (2) the results of the feasibility test according to media experts are that this system has very attractive visuals, is user friendly, is compatible with Windows and Linux and the media size is not too large; and (3) the results of the experiment using an indication of the size of the room and the amount of lux to be achieved, obtained data on the number of lamps according to the calculation using the formula.
\end{abstract}

Keywords: Learning Media, Electrical Installation, Development, Delphi

\section{Introduction}

Learning Media is a learning tool that is used by someone by using tools that are made to facilitate the delivery of material when teaching at school. Things like that really help teachers in teaching in schools and are a solution to make students happy when learning and not feel bored. One of the learning materials in Vocational High Schools is electrical installation material. Introducing electrical installation material will be very difficult if only with books. Therefore this study aims to adopt material about electrical installations in a computer system. This system is called the Electrical Installation Learning Media in Delphi Language. This system is used to determine the number of light points on an electrical installation from the room size indicator and the amount of lux to be achieved. In addition, the system provides a brief description of the electrical installation material. In this system the electrical installation input data is entered into the computer manually. In building this system, Delphi 7 and Inno Set Up Compiler software are used as installers.

\section{Literature Review}

In electrical installations, determining the number of electrical installation components is very necessary, such as determining the number of cables used, sockets, lights, switches, mcbs used and what loads will be installed so that it will determine how many installation components to be installed [1]. In determining the number of components to be installed in a building, the first thing that must be done is that we determine the design of the house and what loads will be installed.

\section{a. Home design}

With the house design, it will be easier to determine the number of electrical installation components. For example, by determining the area of the house to be installed, we can determine the length of the cable to be used, the number of 
lamps required, the number of sockets and other components. Not only that, by determining the design of the house, we can also determine how much power will be installed to meet the needs of the house. Below is an example of a house design that will later create a single line diagram, wiring diagram, piping.

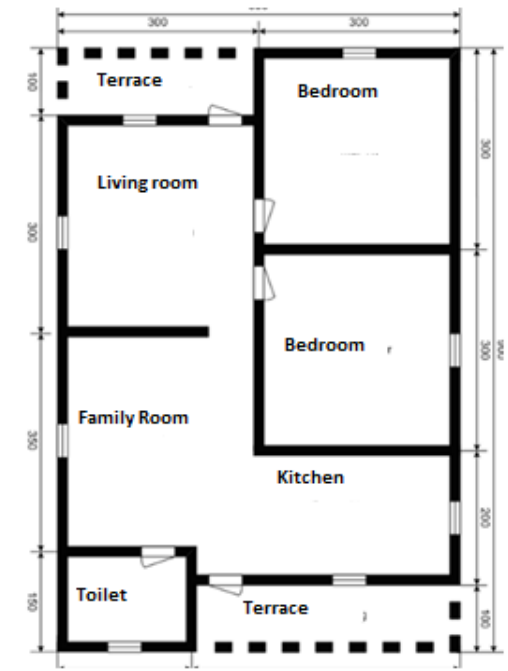

Fig 1.Home Design

\section{b. Load data}

After determining the design of the house, what we can do after that is to determine what loads we will use for the house. This is very important because by managing load data we can determine how much power the building will use. What is meant by load here includes electronic devices (fans, air conditioners, tvs, etc.) And lighting. From the load data we can determine the appropriate safety device (mcb, elcb, etc.).

\section{Calculation}

There are several calculations that must be determined in a plan. In planning a home lighting installation, several things that must be calculated are [4] :

a. Number of light points

b. The number of air conditioning needs

c. The power to be installed

d. Cross-section of the conducting cable

Table 1. Lamp Lumen And Lux Data

\begin{tabular}{|c|c|c|c|}
\hline Room Function & $\begin{array}{l}\text { Lighting Level } \\
\text { (lux) }\end{array}$ & $\begin{array}{c}\text { Color } \\
\text { moderation } \\
\text { group }\end{array}$ & Information \\
\hline Terrace & 60 & 1 or 2 & \\
\hline Living Room & $120-250$ & 1 or 2 & \\
\hline Dining Room & $120-250$ & 1 or 2 & \\
\hline Working Room & $120-250$ & 1 or 2 & \\
\hline Bed Room & $120-250$ & 1 or 2 & \\
\hline Bathroom & 250 & 1 or 2 & \\
\hline Kitchen & 250 & 1 or 2 & \\
\hline Garage & 50 & 1 or 2 & \\
\hline \multicolumn{4}{|c|}{ Office } \\
\hline Director Room & 350 & 1 or 2 & \\
\hline Working Room & 350 & 1 or 2 & \\
\hline Computer Room & 300 & 1 or 2 & $\begin{array}{c}\text { Use lattice amateurs to prevent the consequences } \\
\text { of light reflection }\end{array}$ \\
\hline Image Room & 750 & 1 or 2 & \\
\hline $\begin{array}{c}\text { Archive } \\
\text { Wharehouse }\end{array}$ & 150 & 1 or 2 & \\
\hline \multicolumn{4}{|c|}{ Education } \\
\hline Classroom & 250 & 1 or 2 & \\
\hline Library & 300 & 1 or 2 & \\
\hline Laboratorium & 500 & 1 & \\
\hline Image room & 500 & 1 & Use local lighting on the drawing table \\
\hline Canteen & 750 & 1 & \\
\hline
\end{tabular}

By looking at the data table lumen lamp and lux required for each room, we can find the number of light points that will be installed in each room according to their needs. The following formulas will be used:

The formula for finding the number of light points: 


$$
N=\frac{E x L x W}{\operatorname{rrr} r \mathrm{rr}}
$$

The standard description formula does not exceed $10 \mathrm{~W} / \mathrm{M}^{2}$

Information :

$$
N=\frac{N x \operatorname{Lamp} \text { power }}{\mathbf{n}}
$$

$\mathrm{N}=$ number of light points

$\mathrm{E}=$ light strength to be achieved (lux)

$\mathrm{L}=$ length of space (meters)

$\mathrm{W}=$ width of the room (meters)

$\varnothing=$ total lumen of the lamp / lamp luminous flux

LLF $=$ light loss factor $(0.7-0.8)$

$\mathrm{CU}=$ utilization factor $(50-65 \%)$

$\mathrm{n}=$ number of lamps in 1 light point

\section{Methods}

The method of implementing this research is quantitative. Where quantitative methods are used to collect and determine the data needed in determining the number of light points in electrical installations. The research procedure flowchart will be shown as follows in fig 2 .

\subsection{Data Collection Methods}

The method used in collecting knowledge data about learning media, calculating electrical installations, and algorithms and the delphi ${ }^{\mathrm{TM}}$ programming language on the embarcadero delphi 7 development tool is obtained as follows:

a. study literature from books, journals and online information from internet media.

b. interviews with experts in the field of electrical installations, namely Dr. Irwanto, MT.

c. conduct independent learning and training programs related to the analysis of electrical installations and the preparation of a program using embarcadero delphi 7.

\subsection{Data Analysis Methods}

The data analysis method used in this research is quantitative method. The quantitative method is used where after testing to find out the results of the calculation of electrical installations compared to the value between the results of calculations through software and manual calculations.

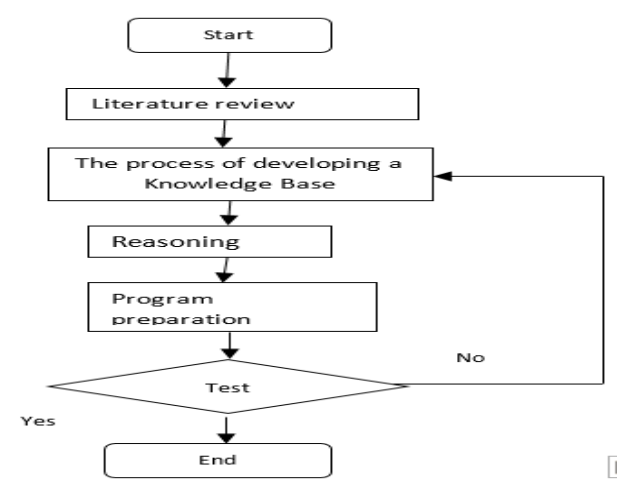

Fig 2. Flowchart

\section{Results And Discussion}

\subsection{Implementation Results}

The results of the implementation of the use of the delphi 7 program for learning media for electrical installations, especially in the field of lighting electrical installations, help students to understand formulas and also make it easier for educators to teach material because there is assistance in the form of digital learning media that can be installed on every laptop and speed up making technical drawings for a building . In figure 2 below, you can see the login dialog box which requires users to log in using an account in order to access existing learning media. Users are required to enter a user name and password. If the user does not enter the correct username and password, the next program will not be able to open. In figure 3, you can see the material dialog box containing material about electrical installations along with the calculation formula for determining the number of light points. On this menu the user can learn the material that has been prepared. There is an advanced and also exit menu where the continue button is connected to the calculation menu and the exit button is used to exit the material menu. In figure 4, you can see the calculation dialog box containing calculations to determine the number of light points where there is an edit menu to enter the input value for each formula unit. To make it easier, the user is only asked to enter 
each value in the specified column so that the results will come out immediately. Then if the user wants to see the formula again, you can press see the formula which is the material menu.

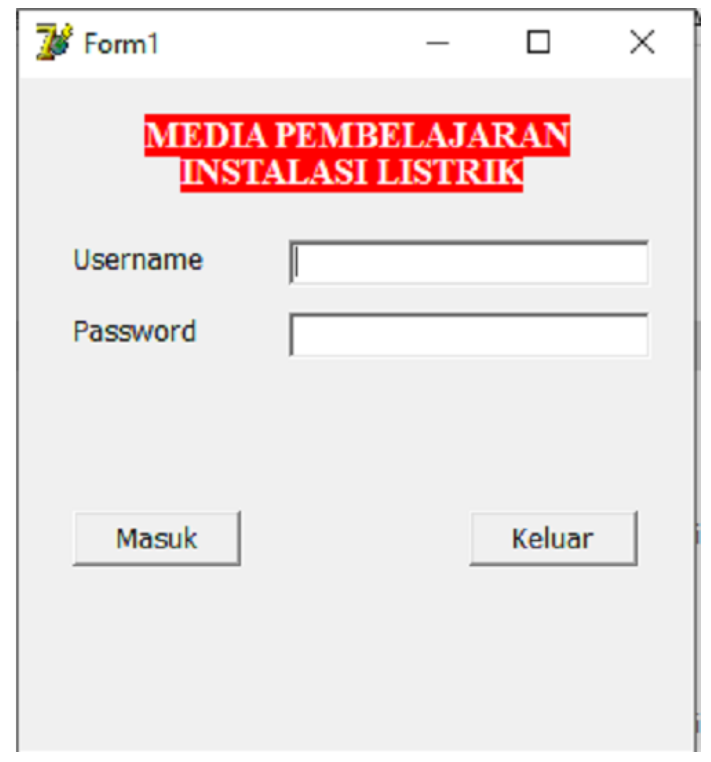

Fig 3. Login Display

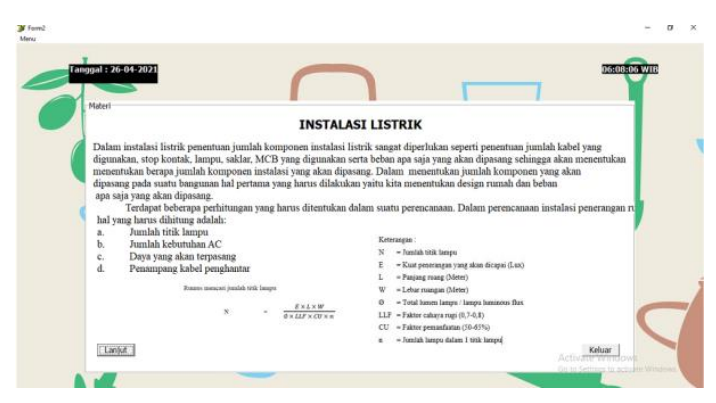

Fig 4. Content Display

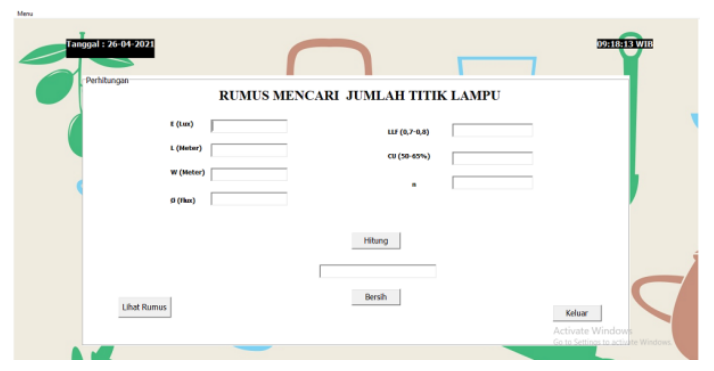

Fig 5. Calculation Display

\subsection{Table}

The tables used in this paper are:

Table 2. Data On Observation Results 1

\begin{tabular}{|c|c|c|c|c|c|c|c|c|c|}
\hline \multicolumn{10}{|c|}{ Living Room } \\
\hline No & $\mathrm{E}(\operatorname{Lux})$ & $\mathrm{L}(\mathrm{m})$ & $\mathrm{W}(\mathrm{m})$ & Flux & $\operatorname{LLF}(0,07-0,08)$ & CU $(50-60 \%)$ & $\mathrm{n}$ & Theory Calculation & Program Calculation \\
\hline 1 & 120 & 5 & 10 & 10 & 0,07 & 50 & 2 & 85,71428571 & 86 \\
\hline 2 & 120 & 7 & 12 & 15 & 0,07 & 50 & 3 & 64 & 64 \\
\hline 3 & 120 & 9 & 14 & 20 & 0,07 & 59 & 4 & 45,76271186 & 46 \\
\hline 4 & 120 & 11 & 16 & 25 & 0,07 & 50 & 5 & 48,27428571 & 48 \\
\hline 5 & 120 & 13 & 18 & 30 & 0,07 & 50 & 6 & 44,57142857 & 45 \\
\hline
\end{tabular}


Table 3. Data On Observation Results 2

\begin{tabular}{c|c|c|c|c|c|c|c|c|c}
\hline \multicolumn{10}{c}{ Canteen } \\
\hline No & E(Lux) & L $(\mathrm{m})$ & W $(\mathrm{m})$ & Flux & LLF $(0,07-0,08)$ & CU (50-60\%) & $\mathrm{n}$ & Theory Calculation & Program Calculation \\
\hline 1 & 250 & 5 & 10 & 10 & 0,07 & 60 & 2 & 148,8095238 & 149 \\
\hline 2 & 250 & 7 & 12 & 15 & 0,07 & 60 & 3 & 111,1111111 & 111 \\
\hline 3 & 250 & 9 & 14 & 20 & 0,07 & 60 & 4 & 93,75 & 94 \\
\hline 4 & 250 & 11 & 16 & 25 & 0,07 & 60 & 5 & 83,80952381 & 84 \\
\hline 5 & 250 & 13 & 18 & 30 & 0,07 & 60 & 6 & 77,38095238 & 77 \\
\hline
\end{tabular}

The test results in tests 1 and 2 above are obtained: after knowing the data, the data is entered into the program to find out the number of light points in the electrical installation. By entering the data obtained from field observations into the calculation form, the results of the comparison between the number of light points calculated by the formula and the calculation using a program such as in tables 1 and 2 from tables 1 and 2 it can be seen that the difference in the number of light points in the formula calculation and the program does not experience a difference (error percentage $=0 \%$ ). Thus, it can be said that this program has succeeded in counting the number of light points and their classification correctly. From the above test, it can be concluded that this program can determine the number of light points by entering several indications of electrical installations.

The advantages and disadvantages of this learning media are:

Advantages:

According to Dr. Irwanto, MT as an expert in the field of electrical installations said that from the test results on monday 1st march 2021, learning media for electrical installations using the delphi program can function properly.The existence of electrical installation materials can help to calculate the correct number of light points in an electrical installation. In addition, this learning media contains an explanation of the electrical installation material. With this, it will be able to help with learning in smk.

Deficiency :

This learning media material contains material for calculating light points based on the area of a building and the amount of flux, so it is necessary to add more lag in terms of material about electrical installations.

\section{Conclusion}

Based on the results of research on the development of learning media, it can be concluded that the development of learning media for electrical installations with the delphi language for vocational schools has been built based on development steps. The advantage of this media is that it can be accessed via a PC or laptop. Already have material facilities about electrical installations and the formula for determining the number of light points.

\section{References}

[1] ADJIE, M. I. (2015). Perencanaan Instalasi Rumah Tinggal. Bekasi: Unisma.

[2] Fadli,Arie. 2010. Sistem Pakar Dasar.pdf. IlmuKomputer.Com

[3] Irwanto,.2021.Komunikasi Pribadi.

[4] Hidayat, A. A. (2019, Oktober 1). ESDM: Kebutuhan Listrik Nasional Naik 6,9 Persen Tiap Tahun. Retrieved from Tempo.Co: tahun/full\&view=ok.

[5] Tri Atmoyo, Bagus.2011. Sistem Pakar Untuk Manual Perbaikan Citra Untuk Evaluasi Radiografi Industri.Yogyakarta:STTN BATAN. 